\title{
ASSESSING THE IMPACT OF CANAL NETWORK ON SURFACE WATERLOGGING USING REMOTE SENSING DATASETS IN ROHTAK DISTRICT, HARYANA
}

\author{
Suvrat Kaushik ${ }^{1, *}$, Pankaj R. Dhote ${ }^{1}$, Praveen K. Thakur ${ }^{1}$, Shiv Prasad Aggarwal ${ }^{1}$ \\ ${ }^{1}$ Water Resources Department, Indian Institute of Remote Sensing, Dehradun, India - (suvrat, pdh, praveen, spa)@iirs.gov.in
}

Commission V, SS: Natural Resources Management

KEYWORDS: Waterlogging, Canals, Remote Sensing, GIS, Rohtak

\begin{abstract}
:
Remote Sensing is a very reliable and expeditious technique for assessment and mapping of surface waterlogged areas. In this study band ratio based NDWI index (Normalized Difference Water Index) was used for extracting water pixels from optical imageries. To overcome the limitation of false positives and cloud penetration associated with optical imageries waterlogged areas was also extracted using SAR (Synthetic Aperture Radar) images. Thresholding of NDWI for optical image and Sigma0 for SAR images was done using their respective histograms to distinguish water and terrestrial features. The total surface waterlogged areas in the district was calculated by integrating the results from both optical and SAR images. It was found that surface waterlogged areas varies temporally from pre-monsoon to post-monsoon period in Rohtak district, Haryana. The surface waterlogged area for pre monsoon period is around $9.7 \mathrm{~km}^{2}$ and for post monsoon period is $17.86 \mathrm{~km}^{2}$. The canal and surface drain network in the district was digitized using the high resolution Sentinel 2 MSS images. Since most of the canals in the area are unlined a buffer of $500 \mathrm{~m}$ either side of the canals and surface drains was considered to assess the impact of seepage and leakage from canals and surface drains. It was found that more than $50 \%$ of the total surface waterlogged areas fall within this buffer, clearly indicating the contribution of leakages from canals and surface drains on surface waterlogging.
\end{abstract}

\section{INTRODUCTION}

The introduction of canal and modern irrigation practices have helped to increase agricultural production. However, losses from the irrigation systems, particularly in areas underlain with poor quality groundwater, have endangered considerable area with the problem of waterlogging and soil salinity (Barney, 1980). Water logging is a condition where the soil upper strata become fully saturated with water and the plant roots get deprived of oxygen to breathe. (Prakash and Mohan, 2016). Surface waterlogging is the accumulation of surface runoff and thereby stagnation of water over depressed lands due to blockage of natural drainage and/or higher water level at the outfalls (Lohani et al., 1999). Water logging is not always due to rising of water table, it may be due to very poor drainage capacity of the rooted zone of the soil. Artificial or man-made causes of waterlogging may be due to leakages from unlined canals and surface drains, faulty irrigation practices resulting in loss of water and restriction to flow of water by construction of roads and railway lines. In India, about 6 to 10 million hectares of irrigated area suffer from waterlogging (Vohra 1980).

For irrigation to be successful the excess water and salts from the soils should be permanently removed. Ancient civilization thrived in canal irrigated areas, they also vanished in the course of time as lands have to be abandoned due to waterlogging and soil salinization (Singh, 1994). It is important to note that, in most of the canal irrigated regions of India, the geographical and/or geological conditions restricts natural drainage of the excess water and the problems of waterlogging and soil salinization are developing. The threat of waterlogging and soil salinity in the Indus basin was recognized soon after the introduction of large scale irrigation systems (Ahmed and Chaudhary, 1988). Lack of adequate drainage has probably

\footnotetext{
${ }^{*}$ Corresponding author
}

been the greatest single cause of failure of irrigation projects throughout the world. Mehta (2000) has also demonstrated that the main cause of waterlogging in the low lying areas is due to seepage from irrigated uplands and seepage from canal water with inadequate water management practices

According to a study conducted by Central Soil Salinity Research Institute (CSSRI) nine districts of Haryana are hit by the problem of soil salinity and waterlogging (The Tribune report, 16 January, 2016). Out of the nine districts, Rohtak district is worst affected by the problem of waterlogging. The geological location of Haryana with the Himalayan Mountains on the north-east and the Thar Desert on the south west leads to mainly inland drainage conditions and an extensively closed basin. Both surface and sub-surface water flow towards this depression and eventually stagnates thus resulting in problems of a rising water table, waterlogging, flooding after heavy rainfall and soil salinization (Sahu, 2014). This problem is further compounded by the leakages from unlined canals and surface drains. The net irrigated area in Rohtak district is 1250 $\mathrm{km} 2$, out of which $840 \mathrm{~km} 2$ area is irrigated by canals. Although the introduction of canal and modern irrigation practices have helped to increase agricultural production, losses from irrigation systems especially unlined canals have rendered large areas unproductive in the vicinity of Rohtak district.. Mapping of the surface waterlogged areas was done by using optical and SAR satellite images. Remote Sensing (RS) and geographical information system (GIS) provides an expeditious and reliable alternative to ground surveys for mapping and monitoring of surface waterbodies (Cao et al., 2018). Narayan et al. (1989) classified the wastelands of the entire Indian territory (329 m ha) using Landsat- MSS FCC of 1:10,00,000 scale into various classes defined as salt-affected, gullied or ravine, waterlogged or marshy, undulating upland with or without scrub, jhum or forest blank, sandy areas (coastal or 
desert), barren hill ridge or rock outcrops and snow covered/glacial areas. Singh and Srivastava (1990) in their study used microwave radiometers for identifying waterlogged and salt affected areas in coastal regions. Various numerical calculations of brightness and temperature were carried out to distinguish waterlogged and salt affected areas. The results presented in this study showed the utility of microwave radiometers in mapping of waterlogged and salt-affected areas. In the present waterlogged areas were mapped using optical and SAR images of Sentinel 2 and Sentinel 1A respectively. Further, the study tries to assess the impact of leakages and seepage on surface waterlogging in areas close to the network of canals and surface drains in Rohtak district of Haryana.

\section{STUDY AREA}

The study area chosen for the study is the Rohtak district of Haryana state (Fig. 1). The total geographical area of the district is $1745 \mathrm{~km}^{2}$. The total geographical area of the basin is $1365.21 \mathrm{~km}^{2}$. Physiographically the district is divided into two major physiographic units i.e. old Alluvium and Fluvio-aeolian plain. The older alluvial plain is formed due to deposition of alluvial material brought out by rivers. The older alluvial plains are nearly level to gently sloping and occupy mainly the Northern and Central part of the district. The fluvio-alluvial plains are formed due to deposition of Aeolian sandy material over older alluvial soils and occur mainly in the southern and south-western parts of the district. The soil texture in the study area varies from sandy to clayey having a heterogeneous composition with frequent calcium carbonate layers at shallow depths. The sediments consist

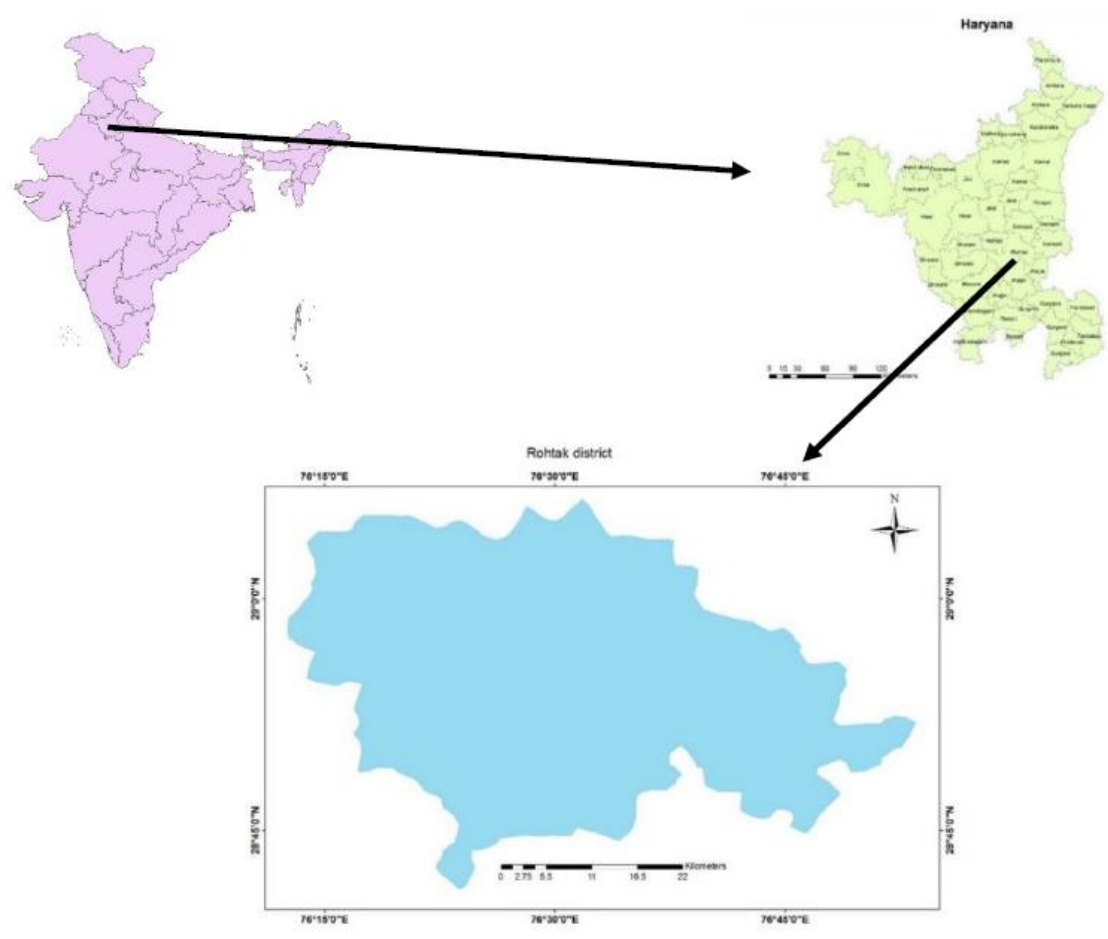

Figure 1. Study Area: Rohtak district, Haryana, India

of sand, silt, clay and kankar etc. Bajra/ Jawar/ Guar, Paddy, Cotton and Sugarcane are the major crops in kharif season (July to October). Wheat, Mustard and Sugarcane are the major crops during Rabi season (November to February) followed by other crops. The two main canals passing through the district are Jawahar Lal Nehru (JLN) feeder canal and Bhalaut Sub. Branch

(BSB) which cover most of the district and spread a network of sub-branches, minors and distributaries. The canals provide adequate water for irrigation mainly in the Kharif season. The water is insufficient in other months and hence groundwater becomes the primary source for irrigation during most of the year. Groundwater in most parts of the district is available at very shallow depths within $5 \mathrm{mbgl}$. The average annual rainfall recorded in the district is $570 \mathrm{~mm}$ (CGWB, 2013). More than $75 \%$ of this rainfall is recorded during the south west monsoons from July to September.

\subsection{Canal and Drainage network:}

Rohtak district is a part of Inland drainage basin. The topography of the district is saucer type, therefore, rain water creates flood problems in monsoon season. In order to avoid flood, drains have been dug out (Fig 2). The main source of draining floodwater is drain no. 8 , which is contributing a lot of ground water recharge. It enters the district in village Sanghi. It flows along the western side of the district headquarter and leaves the district and enters Jhajjar district near Beri. This drain safeguards the district from floods. Two new drains have been dug after 1995 floods to drain off the water of Meham, Lakhan Majra \& Kalanaur area into drain no. 8. These are Meham drain which is $42 \mathrm{Kms}$. and passes through Kalanaur \& Meham blocks covering 33 villages. Second is Lakhan Majra drain, which is $33 \mathrm{Kms}$. Long, covers 23 villages of Meham and Lakhan Majra blocks. These two enter in drain no. 8 at village Kalanaur ultimately going to the river Yamuna. Jawahar Lal Nehru Feeder \& Jhajjar sub branches are the two main canals running in the district with its sub branches, distributaries, minors and subminors. Bhiwani and Kalanaur sub-branches enter in the district in the territory of Meham and Lakhan Mara Blocks 
and feed the area of Kalanaur, Lakhan Majra and Meham blocks. Most of the drainage problem is along canals and its distributaries passing through the district. There is no perennial river in the district. During rains the water, instead of flowing into some rivers, follows a cause directed towards inland depression in eastern and Southern parts of the district and these areas get flooded

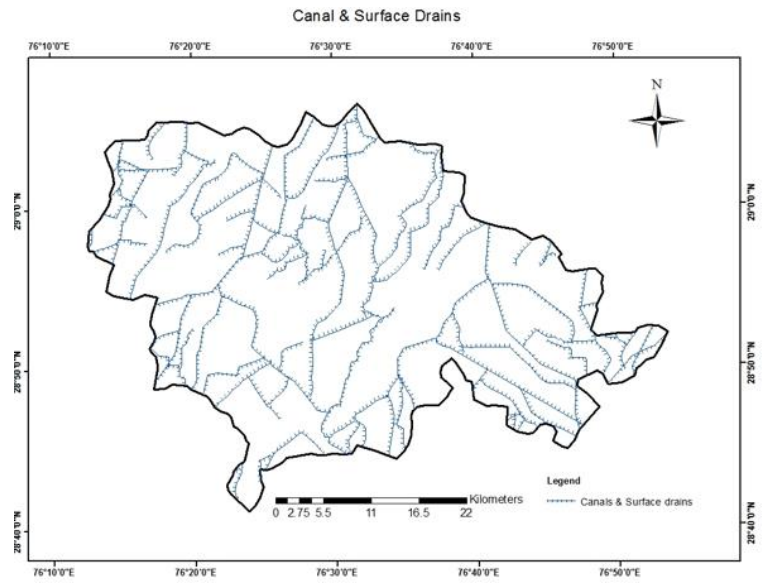

Fig 2: Canal and surface drain network in Rohtak district

\section{METHODOLOGY}

\subsection{Data Sources:}

Sentinal-2 MSS Level 1C data was chosen for the study as it provided high spatial resolution images with good coverage on dates suitable for the study (Table 3 ). Four spectral bands of $10 \mathrm{~m}$ resolution: Band 2 (blue), Band 3 (Green), Band 4 (Red) and Band 8 (NIR) were stacked to generate a standard False Color Composite (FCC) image using band combination 4, 3, 2. Sentinel 1A SAR images (Table 4) were downloaded and processed for almost similar dates to access the surface waterlogging conditions in the district using microwave images.

Table 3: Sentinel 2 MSS data for water pixels extraction

\begin{tabular}{|c|c|c|c|}
\hline $\begin{array}{c}\text { Type of } \\
\text { data }\end{array}$ & $\begin{array}{c}\text { Date of } \\
\text { acquisition }\end{array}$ & $\begin{array}{c}\text { Tile } \\
\text { Number }\end{array}$ & Source \\
\hline $\begin{array}{c}\text { Sentinel 2 } \\
\text { MSS }\end{array}$ & $21 / 12 / 2016$ & T43RFM & $\begin{array}{c}\text { USGS } \\
\text { Earth } \\
\text { Explorer }\end{array}$ \\
\hline $\begin{array}{c}\text { Sentinel 2 } \\
\text { MSS }\end{array}$ & $21 / 03 / 2017$ & T43RFM & $\begin{array}{c}\text { USGS } \\
\text { Earth } \\
\text { Explorer }\end{array}$ \\
\hline
\end{tabular}

Table 4: Sentinel 1A SAR data for water pixels extraction

\begin{tabular}{|l|l|l|l|l|}
\hline Type of data & $\begin{array}{l}\text { Date of } \\
\text { acquisition }\end{array}$ & Polarization & Path & Source \\
\hline Sentinel 1A & $27 / 12 / 2016$ & $\mathrm{VV}+\mathrm{VH}$ & $\begin{array}{l}136 / \\
496\end{array}$ & USF \\
\hline Sentinel 1A & $21 / 03 / 2017$ & $\mathrm{VV}+\mathrm{VH}$ & $\begin{array}{l}136 / \\
496\end{array}$ & $\mathrm{USF}$ \\
& & & 496 \\
\hline
\end{tabular}

\subsection{Extraction of surface waterlogged areas from satellite} images:

Sentinel 2 MSS standard FCC images for pre (Fig 5) and post monsoon (Fig 6) assessment are used to delineate surface waterlogged areas in the district. Multi-band rationing technique combines different relevant bands for improved extraction of water pixels from satellite images (Rokni et al., 2014). Normalized Difference Water Index (NDWI) developed by McFeeters (1996) was used to extract water pixels from the multispectral images and to enhance their presence in the imagery. NDWI is calculated as follows:

\section{Normalised Difference Water Index $(N D W I)=$ GREEN-NIR/GREEN+NIR}

The values for NDWI range from -1 to +1 . NDWI maximizes reflectance of water by using green band wavelengths and minimizes low reflectance of water in NIR spectrum by absorbing the maximum of wavelength. As a result, water features are enhanced owing to having positive values and vegetation and soil are suppressed due to having zero or negative values.

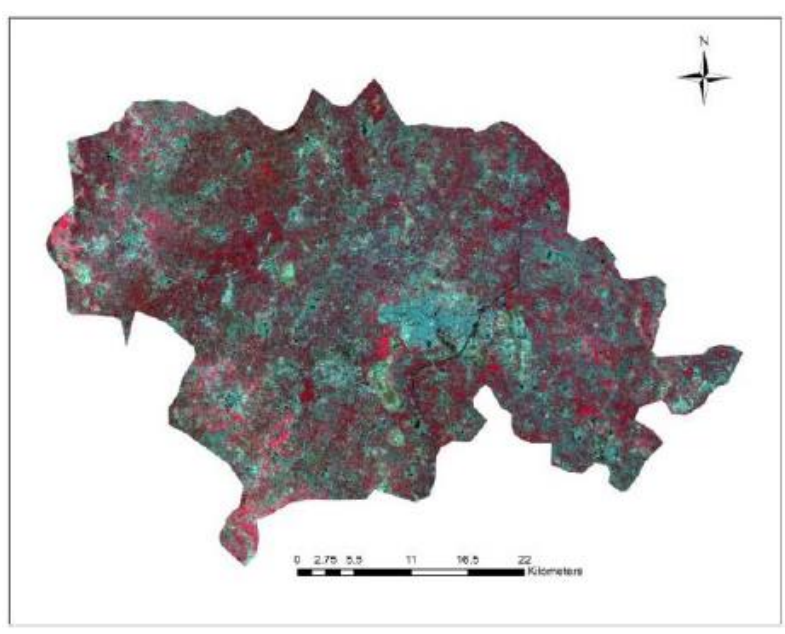

Fig 5: Sentinel 2 MSS (21/12/2016)

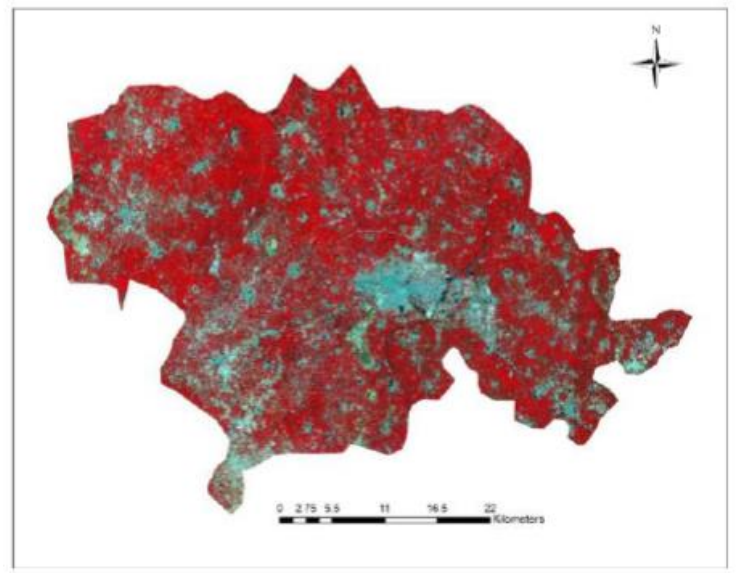

Fig 6: Sentinel 2 MSS (21/03/2017) 


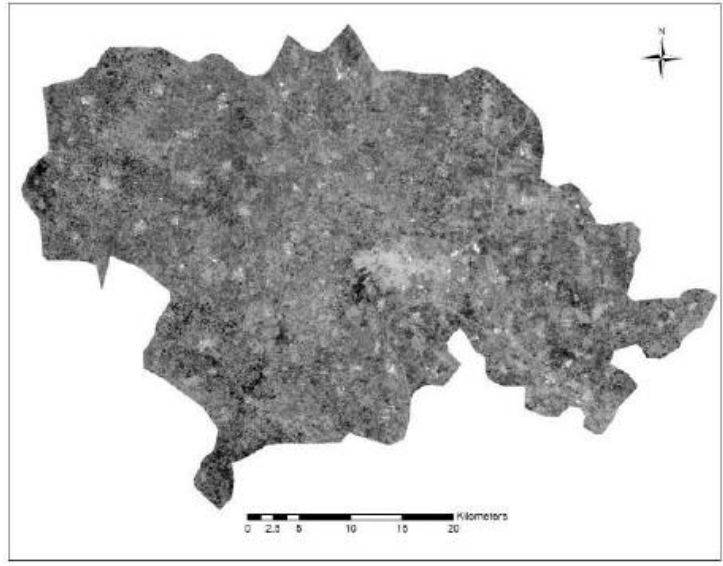

\section{EITHER \$n7_ndwi IF (\$n7_ndwi > 0.20) OR 0 Otherwise}

The condition sets the threshold value of NDWI as greater than 0.20 for any pixel to be classified as water. All other pixels with values less than 0.20 will be classified as 0 and appear dark, while pixels above the threshold value appear bright and will be classified as water.

Fig 7: NDWI image (Post-monsoon)

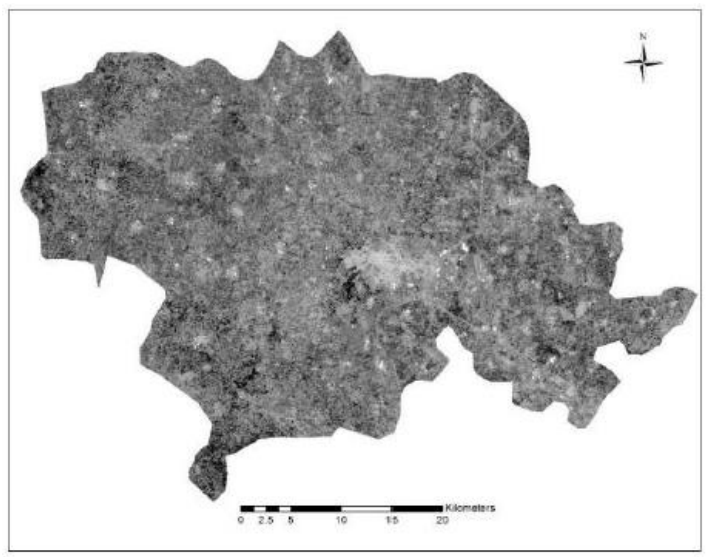

Fig 8: NDWI image (Pre-monsoon)

\subsection{Thresholding of NDWI to extract water pixels:}

The values of NDWI range from -1 to +1 , with water pixels generally showing a higher positive value of NDWI. Thus to extract water pixels from the NDWI image it is important to define a threshold value that best extracts water pixels from the NDWI image. In both the images, it is found that the NDWI for water is greater than 0.20 . The following threshold condition applied on Figs. 7 and 8 in ERDAS Model Maker: 3.5 Thresholding of SAR images to extract water pixels:

The following thresholding condition was applied in ERDAS IMAGINE:

\section{EITHER 1 IF (Sentinel_1A Image $<=-17$ ) OR 0 Otherwise}

The water body images extracted from Sentinel 2 MSS and Sentinel 1A SAR imagery was multiplied to obtain the combined water body map of the study area (Figs. 10 and 11). The images were visually interpreted to separate surface waterlogged areas from other water bodies.

\subsection{Extraction of surface waterlogged areas from SAR images:}

Although NDWI extracts water with good accuracy, it has limitations as in some instances the water features extracted using the NDWI also include false positives from built-up land as observed by (Rokni et al., 2014). During present study it was observed that NDWI thresholding extracted water pixels with sufficient accuracy, but some shallow water areas were not extracted. To overcome this problem Sentinel 1A Ground Range High-resolution Dual-polarization (GRDHD) SAR images acquired for almost similar dates (Fig 6 \& 7) were processed and analysed. The images were calibrated and geocoded in SNAP. The raw Sentinel 1A images were processed to get backscatter images (Sigma0). Median filter of $3^{*} 3$ was applied to the images to separate features distinctly and for better extraction of water pixels. Image to image registration was performed on the Sentinel 1A images with respect to the Sentinel 2 MSS images in ERDAS IMAGINE (ERDAS, 1997). Due care was taken to keep the Root Mean Square (RMS) error less than 1.

Calm water bodies appear very dark in microwave images since they behave as a specular reflector and direct all the backscatter radiation away from the sensor. In the processed Sentinel 1A images the threshold of $\mathrm{Db}$ (backscatter coefficient) values to extract water pixels for both the images was set at -17 .

\section{6: Visual Interpretation:}

Visual interpretation was the most significant and tedious step in the extraction of surface waterlogged areas from satellite imagery. The study area comprises an extensive network of canals and drains that supply water for irrigation. Some artificial tanks or storage structures are also build near major canals to store water. Since thresholding of satellite images extracts all possible surface water bodies present in the FCC, it was imperative that man-made water areas were eliminated from the final estimation of surface waterlogged areas. For this purpose the raster image was converted to a vector image in ArcGIS and all artificial water bodies were manually edited and eliminated from the image. Visual interpretation skills of shape, size, and association were applied to identify artificial man made water structures. The total waterlogged area in the study area was calculated for both pre monsoon and post monsoon period from the vector images.

\section{7: Canal and surface drain buffer:}

The canal and surface drain network map was digitised from the high resolution Sentinel 2 images (Fig. 3). Studies of 1216 horsepower SWI pumps indicate that water can be conveyed from surface sources up to $400 \mathrm{~m}$ from river and canal banks where flexible hose piping is used to reduce losses (Krupnik et al., 2015b). Since most of the canals in the area are unlined a buffer of $500 \mathrm{~m}$ either side of the drain was considered to assess the impact of seepage and leakage from canals and surface drains (Fig. 9) 


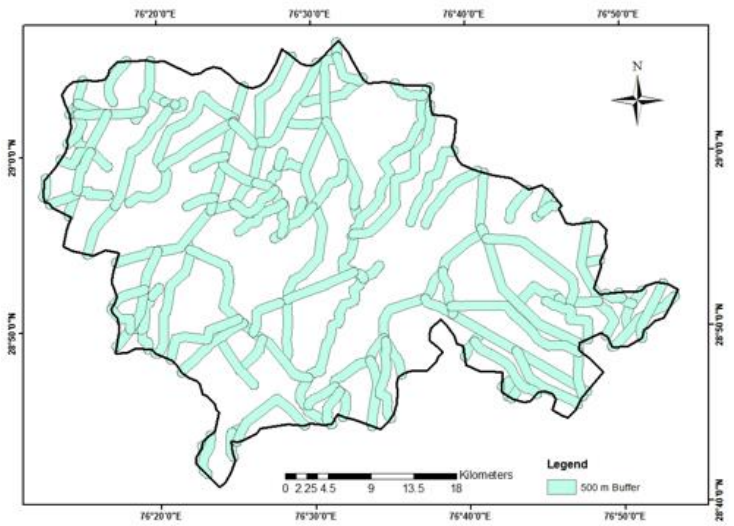

Fig 9: $500 \mathrm{~m}$ buffer around the canal network

\section{RESULTS AND DISCUSSION:}

\section{1: Assessment of surface waterlogged areas in Rohtak} district:

The vector images obtained after running the algorithm in Fig 6 is the surface waterlogged area map for both pre and post monsoon periods (Fig $10 \& 11$ ). The total area of the district that is surface waterlogged is calculated from these images. The blue patches in the images represent existing surface waterlogged areas. It was found that the total area of Rohtak district surface waterlogged is $17.86 \mathrm{sq} . \mathrm{km}$ for post monsoon period (Fig 10). This comprises around 1\% of the total area of the district. The problem of surface waterlogging is more critical in the central and southern parts of the district with almost $65 \%$ of the total waterlogged areas spread in this region (11.75 sq. km). The total surface waterlogged area for pre monsoon period is 9.7 sq. km (Fig. 11). This comprises around $0.55 \%$ of the total area of the district. Surface waterlogged areas for pre monsoon period are almost half the total area in post monsoon period. In many parts of the district surface waterlogging conditions persist from post monsoon period to pre monsoon period. The summers in Rohtak are dry and very hot with maximum temperatures of $45^{0} \mathrm{C}$ recorded in some parts. The persistence of waterlogging from post monsoon to pre monsoon indicates towards permanent waterlogging condition in these areas. The problem of waterlogging is also severe in areas with lower

elevation indicating a natural restriction to flow and stagnation of water in these parts of the district.

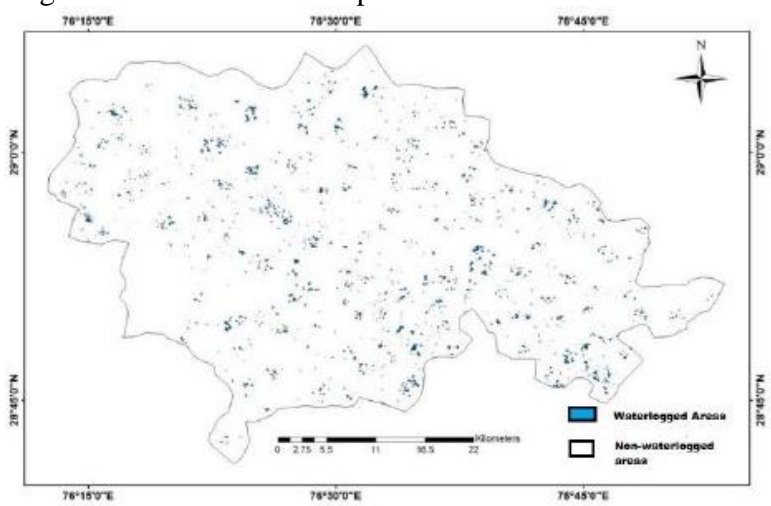

Fig 10: Surface waterlogged areas map (December, 2016)

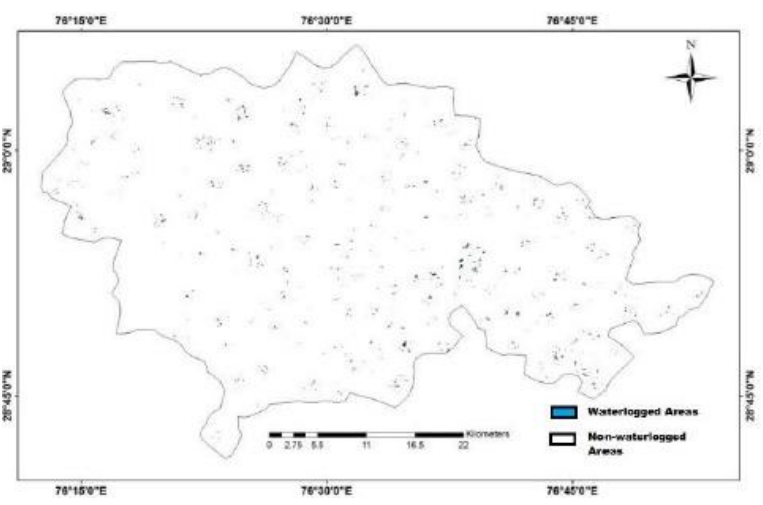

Fig 11: Surface waterlogged areas map (March, 2017)

\section{2: Impact of surface drains and canals on surface waterlogging:}

The district has an extensive network of canals. The network is especially very dense in the central and southern parts of the district. Leakages and seepage from canals can lead to surface and sub-surface waterlogging. The results obtained from intersection of the surface waterlogged areas and the buffer map show similar trend. The influence area from the canals and surface drains was set at $500 \mathrm{~m}$. The following results were obtained.

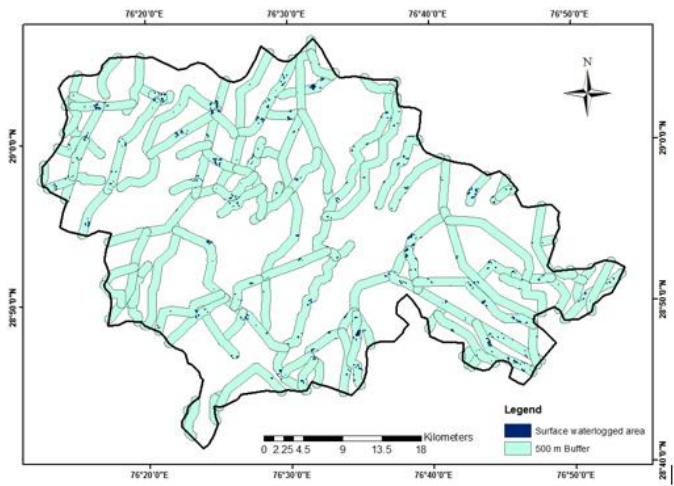

Fig 12: Surface waterlogged areas within the canal buffer (Pre-monsoon)

Table 13: Results of surface waterlogged areas within canal buffer (Pre-monsoon)

\begin{tabular}{|c|l|l|}
\hline Buffer area & $\begin{array}{l}\text { Surface } \\
\text { waterlogged } \\
\text { area within } \\
\text { buffer }\left(\mathbf{k m}^{2}\right)\end{array}$ & $\begin{array}{l}\text { \% of surface } \\
\text { waterlogged } \\
\text { area within } \\
\text { buffer }\end{array}$ \\
\hline $500 \mathrm{~m}$ & 5.1 & \multicolumn{1}{|c|}{52.55} \\
\hline
\end{tabular}




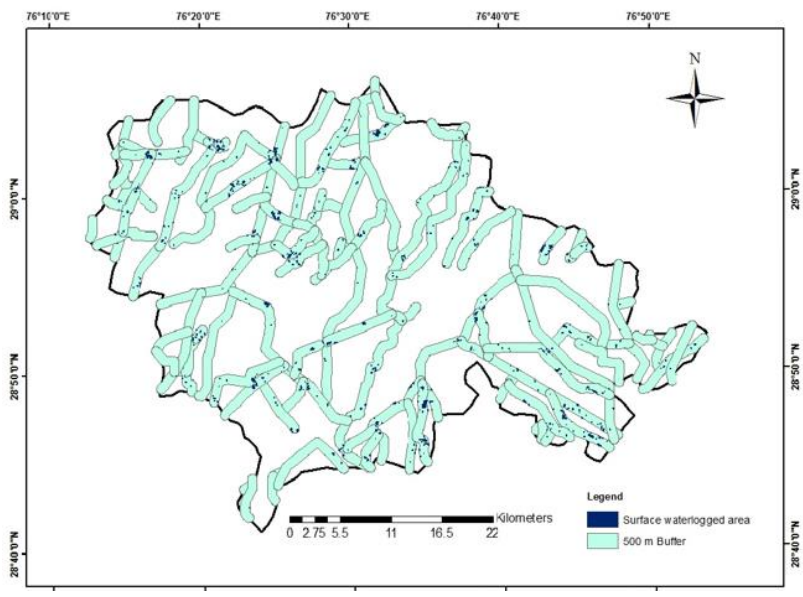

Fig 14: Surface waterlogged areas within the canal buffer (Post-monsoon)

Table 15: Results of surface waterlogged areas within canal buffer (Post-monsoon)

\begin{tabular}{|c|l|l|}
\hline Buffer Area & $\begin{array}{l}\text { Surface } \\
\text { waterlogged } \\
\text { area within } \\
\text { buffer }\left(\mathbf{k m}^{2}\right)\end{array}$ & $\begin{array}{l}\text { \% of surface } \\
\text { waterlogged } \\
\text { area within } \\
\text { buffer }\end{array}$ \\
\hline $500 \mathrm{~m}$ & 9.9 & 55.65 \\
\hline
\end{tabular}

As seen from the results discussed in the section 4.1 and from the tables 13 and 14, leakages from unlined canals and surface drains have a definite impact on surface waterlogging in areas in the vicinity of these artificial waterbodies. More than $50 \%$ of the total surface waterlogged areas fall within the buffer of $500 \mathrm{~m}$ on both sides (Figs. $12 \&$ 14, Tables 13 $\& 15)$. Leakages from canals are a major contributing factor to the severe problem of waterlogging persisting in the district, along with the geology and soil type that exist in the study area. A geological depression persists in the area leading to a closed basin like conditions. Water from the higher elevations in the surrounding areas moves towards this depression and eventually stagnates due to poor natural and artificial drainage conditions. The occurrence of clay lenses at most places at shallow depths also accentuates this problem.

\section{CONCLUSIONS:}

The study shows that waterlogging is a major problem in Rohtak district especially during post monsoon months. Around $9.7 \mathrm{~km}^{2}$ area of the district is surface waterlogged in pre monsoon period and increase up to $17.86 \mathrm{~km}^{2}$ during post monsoon. The results of canal buffer of $500 \mathrm{~m}$ shows that $52.55 \%$ of the total surface waterlogged area falls within vicinity of a canal or surface drain for pre-monsoon period while $55.43 \%$ for post monsoon, indicating that the main reason for surface waterlogging is the leakage from the extensive canal and drainage network in the district. This combined with poor drainage facilities aggravates the problem. Both preventive and curative measures have to be adopted for the management of waterlogged areas.

\section{REFERENCES}

Ahmed, N. \& Chaudhary, G.R. (1988) Irrigated Agriculture of Pakistan. Shahzad Nazir Publications, Lahore.

Barney G O (1980) The Global Report 201 to the President, The Technical Report, vol. 2, US Government, Washington

Cao G L, Zheng C M, Scanlon B R et al (2013) Use of flow modelling to assess sustainability of groundwater resources in the North China plain. Water Resour Res 49:159-175

Central Ground Water Board (CGWB) (2013) Information booklet, Rohtak district, Haryana

ERDAS Inc., (1997). ERDAS Imagine Tour Guides, ERDAS Inc., Atlanta, Georgia, USA

Krupnik, T.J, S. Santos Valle, M.S. Islam. et.al (2015) Energetic, hydraulic, and economic efficiency of axial flow and centrifugal pumps for surface water irrigation in Bangladesh. Irrig. Drain. 64(5):683-693

Lohani, A.K., Jaiswal, R.K. and Jha, R. (1999) Waterlogged area mapping of Mokama group of Tals using remote sensing and GIS. Journal of Institution of Engineers. 80(1):133-137

McFeeters S K (1996) The use of normalised difference water index (NDWI) in the delineation of open water features. Int. J. Remote Sens 17(7):1425-1432

Mehta, M. (2000) Waterlogging in India. Bhu-Jal News, $15(1 \& 2) 35-38$

Narayan, L.R.A, Rao, D.P. \& Gautam, N.C (1989) Wasteland identification in India using satellite remote sensing. International Journal of Remote Sensing. 10(1): 93106

Prakash Ved and Chander Mohan (2016) Water logging and salinity: Issues and challenges in restoring the land resource. Int. j. multidiscip. 3(5):341-344

Rokni, Komeil, Anuar Ahmad, Ali Selamat, and Sharifeh Hazini (2014) Water Feature Extraction and Change Detection Using Multitemporal Landsat Imagery. Remote Sensing 6.5: 4173-189

Sahu (2014) Identification and mapping of the waterlogged areas in Purba Medinipur part of Keleghai river basin, India: RS and GIS method. Int J Adv Geosci 2(2):59-65

Singh R P, Srivastav S K (1990) Mapping of waterlogged and salt-affected soils using micro wave radiometers. Int $\mathbf{J}$ Remote Sens 11(10):1879-1887

Singh, N.T (1994) Land and water management in north and north western India. Management of Land and Water Resources for Sustainable Agriculture and Environment. New Delhi. Indian Society of Soil Science, 95-120.

Vohra B B (1980) A policy for land water, Sardar Patel Memorial Lecture, Department of Environment, Government of India, New Delhi 